\title{
P98 - Gluten allergy
}

\author{
Estefânia Barrosa Maia*, Loureiro Carla Chaves, Sónia Lemos, José Antonio Pinheiro \\ From 3rd Pediatric Allergy and Asthma Meeting (PAAM) \\ Athens, Greece. 17-19 October 2013
}

\section{Background}

Gluten is a mix of cereals proteins (glutenins and gliadins) and can cause two distinct immunological diseases: celiac disease and IgE-mediated gluten allergy (GA). There are few cases of GA reported and little is known about its natural history.

\section{Methods}

Description of GA in children followed at ours Pediatric Allergy Clinic: clinical manifestations, laboratory data, comorbidities and follow-up.

\section{Results}

Nine children with GA are followed at our Pediatric Allergy Clinic, with ages ranging from 1-14 years and 8 are boys. Early presentation occurred between 5 and 9 months of age: 6 with cutaneous manifestations, 2 with gastrointestinal manifestations and 1 with anaphylaxis. The route of sensitization was cutaneous (with oat cream) and by food ingestion. Serum specific IgE to gluten ranged from 0,73 to $100 \mathrm{KUI} / \mathrm{L}$. Four children had specific IgE to other cereals without gluten (corn and rice). All children exhibited other atopic diseases. Eight children had multiple food allergies (egg, milk or fish). Four children developed respiratory allergy (asthma and rhinitis) and 2 of them had specific IgE to cereals pollens. All children adopted a gluten free diet and have adrenaline self-injectors. Two patients suffered anaphylaxis episodes after the diagnosis and 3 children resolve their GA (1, 2 and 6 years).

\section{Conclusions}

GA is a rare disease, and can be life-threatening. Clinical presentation occurs in the first year of life and cutaneous manifestations are the most common. This allergy may resolve during childhood or become persistent. Atopic dermatitis can be an early manifestation of disease and

\footnotetext{
Hospital Pediatrico, Centro Hospitalar e Universitário de Coimbra, Coimbra,
} Portugal

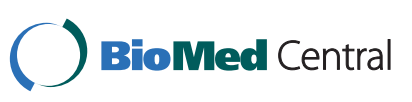

(c) 2014 Barrosa et al; licensee BioMed Central Ltd. This is an Open Access article distributed under the terms of the Creative Commons Attribution License (http://creativecommons.org/licenses/by/2.0), which permits unrestricted use, distribution, and reproduction in any medium, provided the original work is properly cited. The Creative Commons Public Domain Dedication waiver (http:// creativecommons.org/publicdomain/zero/1.0/) applies to the data made available in this article, unless otherwise stated. the route of sensitization can be cutaneous. Exacerbation of atopic dermatitis with oat creams may alert to this diagnosis. Multiple food allergy is frequent in children with GA.

Published: 28 February 2014

doi:10.1186/2045-7022-4-S1-P153

Cite this article as: Barrosa Maia et al:: P98 - Gluten allergy. Clinical and Translational Allergy 2014 4(Suppl 1):P153. and take full advantage of:

- Convenient online submission

- Thorough peer review

- No space constraints or color figure charges

- Immediate publication on acceptance

- Inclusion in PubMed, CAS, Scopus and Google Scholar

- Research which is freely available for redistribution
Submit your next manuscript to BioMed Central 